\title{
The Importance of Environmental Material

\author{
in Indonesian Language Learning
}

Dina Oktaviani/19016015

dinaoktaviani021000@gmail.com

The environment has both positive and negative impacts on humans. Positive impacts if the environment is well maintained and negative impacts if the environment is not maintained. The environment has an impact on humans in the health sector and also affects the community's economy. An untreated environment can also cause disasters that will harm humans for their lives. It is the environment that influences the good or bad of human behavior. This is because the influence of the environment is very large in everyday life.

According to Tung and Wihardjo (in Ramadhan et al, 2019) problems that occur in the environment are caused by careless and intensive human activities in the area where they live, this is done to improve the quality of their lives. Many people don't think about the environment when they do things that can damage the environment. Most of them only think about themselves and do not think about any impact that will occur from their actions.

The impact of his actions such as littering will result in polluted environment and flooding. This is because of the selfish attitude that exists in humans. According to Erdoan, Wang J, and Uyar Y (in Ramadhan et al, 2019), it takes individuals who are aware and responsible for the environment in order to overcome this problem. So that the environment can improve and so will the quality of life. This can be achieved by connecting the environment with other fields of science such as the field of education which is more specialized in environmental education.

Ramadhan et al (2019) say that environmental education is important to increase students' attitudes and awareness of the environment. Environmental education can make students think critically and contextually. This critical and contextual way of thinking will later affect Indonesian language learning, so that environmental education and language learning are interrelated. Putri and Syahrul (2019) revealed that in learning in a school environment, teaching reading must receive serious attention from educators in Indonesia. Through teaching, educators are able to direct students in language learning.

According to Nkwetisma (in Ramadhan et al, 2019), environmental education is a conscious effort to teach and attract human attention about how the natural environment functions and how humans can manage and protect it. Not only students, teachers also need to think creatively in utilizing the environment to be used as learning media. Therefore, the teacher is a facilitator for the students. This is in line with the statements of Sukma (2012) and 
Ramadhan et al (2019), namely the teacher functions as a facilitator and learning manager in the learning process. According to Lai and Buldur (in Ramadhan et al, 2019), environmental education can be applied in the direct learning process in the classroom. In learning Indonesian, you can connect material about the environment with the materials being taught.

Language teachers play an important role in integrating environmental education in language learning. Teachers can use global issues as a context for developing language skills. This context can be integrated into the text being studied. In accordance with the language learning curriculum, namely text-based language learning. Through the texts studied, students gain knowledge about the environment and are expected to have an impact on environmentally conscious behavior. Environmental education can be seen through the learning designs used by teachers. Ramadhan et al (2019) revealed that language teachers play an important role in integrating environmental education in language learning. Teachers can use global issues as contexts to develop language skills and these contexts can be integrated into the text being studied.

According to Lai and Buldur (in Ramadhan et al, 2019), environmental education can be applied in the direct learning process in the classroom. In learning Indonesian, you can connect material about the environment with the materials being taught. Ramadhan et al (2018) stated that environmental education is able to help students rethink the relationship or correlation between humans and their environment. The correlation starts from understanding the environment, being aware of environmental problems, and considering environmental problems related to human life.

Based on the author's research $25 \%$ of respondents agree and $65 \%$ strongly agree that material on the environment must be related to learning Indonesian. Respondents consisted of all Padang State University students and middle and high school students. Of the total number of 30 respondents who took part in filling out the questionnaire, 28 female respondents were more dominant and 2 males were respondents with a percentage of $93.3 \%$ female, $6.7 \%$ male. The results of the data from the percentage of questionnaires that have been carried out through the google form can be seen as follows. The first statement, "Online learning is not conducive to learning environment and language" $61.3 \%$ strongly agree, $38.7 \%$ agree, $0 \%$ disagree, and $0 \%$ disagree. The second statement "Environmental material in Indonesian brings positive value for students" $71 \%$ stated strongly agree, $29 \%$ stated agree, $0 \%$ stated less agree, and $0 \%$ disagreed. The third question "Students and teachers are very important in instilling the importance of protecting the environment" 63.3\% stated strongly agree, 33.3\% agreed, $0 \%$ disagreed, and $0 \%$ disagreed. The fourth statement "In learning Indonesian at school, students are required to use Indonesian" $65.5 \%$ stated strongly agree, $35.5 \%$ agreed, $0 \%$ disagreed, and $0 \%$ disagreed. The fifth statement "A beautiful environment will create conducive learning conditions for students in various places of learning, both individually and in groups" 54.8\% stated strongly agree, 45.2\% agreed, $0 \%$ disagreed, and $0 \%$ disagreed. The sixth statement "Environmental material should explain examples of the environment around students" $64.5 \%$ stated strongly agree, 35 , 
5\% agreed, $0 \%$ disagreed, and 0\% disagreed. Seventh statement "There are still many students or students who don't care about the environment, such as a lot of littering, due to lack of further education" $67.7 \%$ stated strongly agree, $32.3 \%$ stated agree, $0 \%$ stated disagree, and $0 \%$ stated do not agree. The eighth statement "Instilling a sense of responsibility and being aware of the environment can be done in schools by applying environmental materials in Indonesian language learning" $61.3 \%$ stated strongly agree, $38.7 \%$ agreed, $0 \%$ disagreed, and $0 \%$ disagreed agree. The ninth statement "Utilization of the environment is one of the good learning media to be applied in the learning process" $58.1 \%$ stated strongly agree, $41,9 \%$ agreed, $0 \%$ said less agree, and $0 \%$ disagreed. The tenth statement "Environmental learning will make students more human towards the environment" $54.8 \%$ stated strongly agree, $45.2 \%$ agreed, $0 \%$ disagreed, and $0 \%$ disagreed.

Based on the results of research that has been done by the author, it can be said that education is important to increase students' attitudes and awareness of the environment. Environmental education can make students think critically and contextually. This critical and contextual way of thinking affects Indonesian language learning, so that environmental education and language learning are interrelated. There is still hope to improve it by increasing environmental awareness among the younger generation. Schools are one of the important roles to make this happen. Environmental education is important to increase students' attitudes and awareness of the environment. Environmental education should be designed to develop students' cognitive, emotional, linguistic and psychomotor development, and support them to develop positive attitudes towards the environment. 


\section{DAFTAR PUSTAKA}

Buldur A and Ömeroglu E. (2018). An examination of the relationship between pre-school children's and their teacher' attitute and awareness towards the environment Journal of Education and Learning 7(2) 221-9.

Nkwetisma C M. (2011). EFL/ESL and environmental education: towards an eco-applied linguistic awareness in Cameroon World Journal of Education, 1(1). 110-18.

Piliang, Wilda S. H., Atmazaki, dan Syahrul Ramadhan. (2014). Kontribusi Kemampuan Apresiasi Sastra dan Berpikir Kreatif terhadap Keterampilan Bermain Drama pada Siswa Kelas XII IPS SMA Negeri 2 Rengat Kabupaten Indragiri Hulu. Jurnal Bahasa, Sastra dan Pembelajaran, 2(2), 75-87.

Ramadhan, S., Yasnur Asri, dan Vivi Indriyani . (2018). Learning Module Design Writing Argumentative Text Based Problem-Based Learning. Advances in Social Science, Education and Humanities Research, Vol 263: 194-200.

Ramadhan, S., Elfia Sukma, dan Vivi Indriyani. (2019). Environmental Education and Disaster Mitigation through Language Learning. IOP Conference Series: Earth and Environmental Science, 314, p. 1-9.

Ramadhan, S., Elfia Sukma, dan Vivi Indriyani. (2019). Persepsi Guru terhadap Penggunaan Bahan Ajar Bahasa Indonesia dengan Perangkat Seluler dan Aplikasi Edmodo. Seminar Internasional Riksa Bahasa.

Sukma, Elfia. (2012). Pembelajaran Sastra yang Integratif Berbasis Kompetensi. International Conference on Languages and Arts, Halaman 432-436.

Zulhafizh, Atmazaki, dan Syahrul Ramadhan. (2013). Kontribusi Sikap dan Motivasi Belajar Siswa terhadap Hasil Belajar Bahasa Indonesia. Jurnal Bahasa, Sastra dan Pembelajaran, Volume 1, Nomor 2, Halaman 13-28.

Tung C Y, Huang C C and Kawata C. (2002). The effects of different environmental education programs on the environmental behaviors of 8th grade students and related factors Journal of Environmental Health, 64(7). 24-9.

Wihardjo S D, Hartati S, Nurani Y and Sujarwanta A. (2017). The effects of green schooling knowledge level and intensity of parental guidance on the environmental awareness of the early age student Educational Research and Reviews, 12(5). 251-57. 